\title{
Health production and determinants of health systems performance in WHO Eastern Mediterranean Region
}

\author{
Abolghasem Pourreza ${ }^{7}$, Vahid Alipour ${ }^{2}$, Jalal Arabloo ${ }^{7}$, Mohsen Bayati $^{7}$ and Bahman Ahadinezhad ${ }^{1}$
}

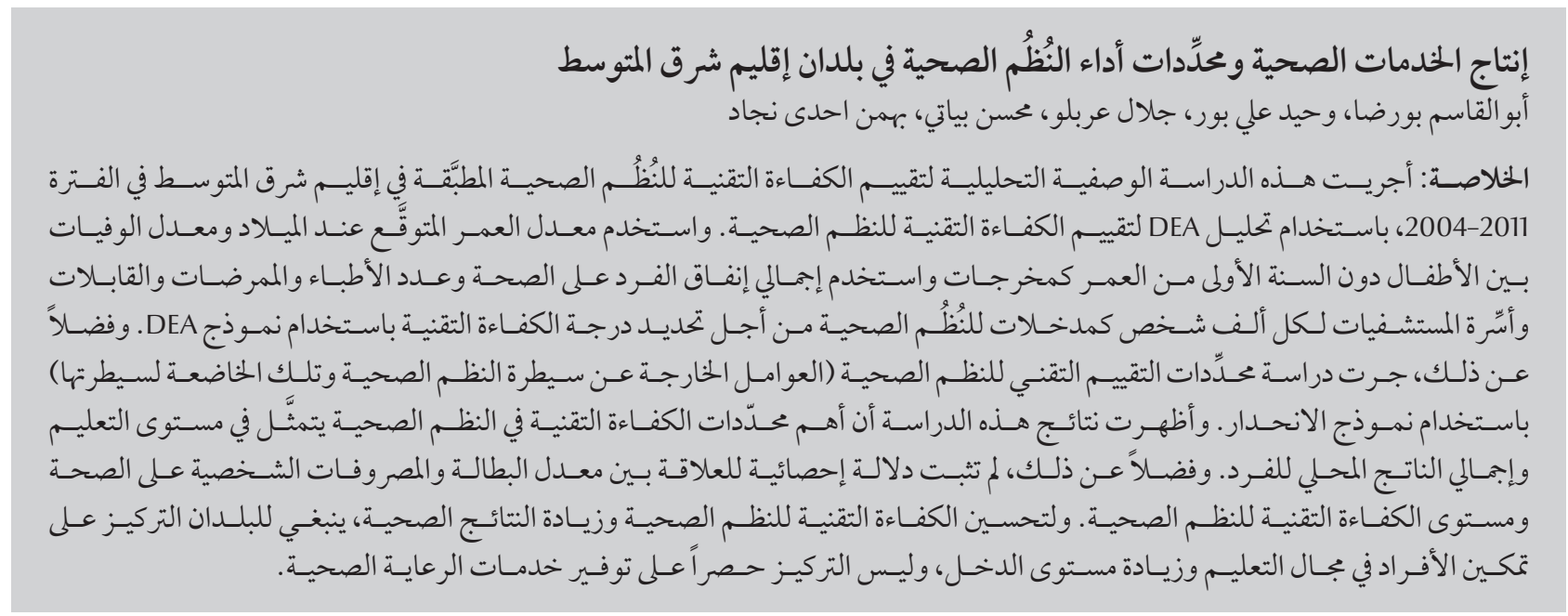

ABSTRACT This descriptive-analytical study used data envelopment analysis to evaluated the technical efficiency (TE) of health systems in Member States of the World Health Organization Eastern Mediterranean Region during 2004-2011. Life expectancy and infant mortality were used as outputs. Per capita total expenditure on health, and number of physicians, nurses and midwives and hospital beds per 1000 people were used as inputs. The determinants of TE of the health systems were examined using a regression model. United Arab Emirates and Somalia had the most efficient health systems with a TE score of 1. Djibouti and Libya had the most inefficient health systems, with TE scores of 0.346 and 0.435 , respectively. The most important determinants of TE were the level of education and gross domestic product per capita. The relationship between unemployment and out-of-pocket health expenditure was not significantly associated with TE of the health systems. To improve TE of the health systems, countries should focus on individuals' empowerment in education and income level, rather than only on providing healthcare services.

\section{Production de résultats sanitaires et déterminants de la performance des systèmes de santé dans la Région OMS de la Méditerranée orientale}

RÉSUMÉ La présente étude analytique descriptive a été menée pour évaluer l'efficacité technique des systèmes de santé des pays de la Région de la Méditerranée orientale de l'Organisation mondiale de la Santé (OMS) durant la période 2004-2011 au moyen de l'analyse d'enveloppement des données. L'espérance de vie à la naissance et le taux de mortalité infantile ont été utilisés comme extrants et les dépenses de santé totales par habitant, les effectifs de médecins, d'infirmières et de sages-femmes et le nombre de lits d'hôpital par millier d'habitants ont été utilisés comme intrants des systèmes de santé. Les déterminants de l'efficacité technique des systèmes de santé ont été examinés à l'aide du modèle de régression. Les Émirats arabes unis et la Somalie avaient les systèmes de santé les plus efficaces avec un score d'efficacité technique de 1, tandis que Djibouti et la Libye, avec des scores d'efficacité technique de 0,346 et de 0,435 respectivement, avaient les systèmes de santé les plus inefficaces. Les déterminants les plus importants de l'efficacité technique des systèmes de santé des pays étaient le niveau d'éducation et le PIB par habitant. La relation entre le taux de chômage et les dépenses de santé directes n'était pas statistiquement significative du niveau d'efficacité technique des systèmes de santé. Afin d'améliorer l'efficacité technique des systèmes de santé, les pays devraient se concentrer sur l'autonomisation individuelle dans les domaines de l'éducation et du niveau de revenu, plutôt que sur la prestation de services de soins de santé uniquement.

'Department of Health Management and Economics, School of Public Health, Tehran University of Medical Sciences, Tehran, Islamic Republic of Iran. ${ }^{2}$ Health Management and Economics Research Center \& Department of Health Economics, School of Health Management and Information Sciences, Iran University of Medical Sciences, Tehran, Islamic Republic of Iran (Correspondence: V. Alipour: vahid.alipoor7360@yahoo.com) Received: 05/09/15; accepted: 08/11/16 


\section{Introduction}

Health systems include all organizations, enterprises and institutions that are engaged in the production and provision of health services. In most countries, health systems play an important and effective role in increasing life expectancy, reducing mortality from disease, and protecting individuals against the costs of illness, therefore, the lives of many people depend on proper functioning of these health systems (1). However, there is evidence that some health systems do not fulfil their vital role, and by inappropriate use of resources and facilities they drift far from their functional objectives, causing inequality, unnecessary suffering and increased poverty in the community. Therefore, improper management of resources, inefficient organization and lack of proper accountability are serious problems causing the failure of health systems. Accordingly, in recent years, the function of health systems has become a major concern for health policy-makers and countries committed to reforms in this area. These reforms include financing, provision of services, and production and development of resources. Thus, it is important to examine the effect of such reforms on the function and technical efficiency (TE) of health systems (2).

In recent years, the average health expenditure has increased from 3.6 to $9.8 \%$ of gross domestic product (GDP) in several countries that are members of the Organisation for Economic Co-operation and Development. In Member States of the World Health Organization Eastern Mediterranean Region, this share increased from 4.9 to $5.7 \%$ during 1999-2011. Also in the latter countries, on average, per capita health expenditure increased from US\$224 in 2004 to US\$431 in 2011 . With increasing healthcare costs, which could reduce resource consumption in other sectors, the productivity of resources devoted to this sector is becoming increasingly important. Although some countries have good health outcomes, their approach to achieving them is inefficient. Some countries also can achieve the desired outcomes by reducing the amount of inputs (e.g., per capita total expenditure on health, and number of physicians). Attempts to adopt several policies to increase the resource efficiency of the health sector requires functional analysis of health systems, in terms of how to use financial and non-financial resources and the factors affecting their health production function (maximum outputs that health systems produce out of a given combination of health inputs) (3).

Some studies have been carried out at the micro level to evaluate the function of health system units such as hospitals and clinics (4-9), and at the macro level to evaluate the TE of health systems (10-14). Most of these studies used life expectancy at birth as an index of output, and per capita health expenditure as an index of input. However, in recent years, different types of inputs and outputs have been used in the regression model. For example, Spinks et al. (10) examined the effect of socioeconomic factors on health outcomes, using variables of unemployment rate, level of education and GDP per capita as inputs in the model. Also, Schwellnus et al. (11) included socioeconomic factors and lifestyle as inputs in the model. Despite the various studies carried out in developed countries regarding the TE and factors affecting their health systems, studies of this kind are rarely carried out in developing countries. Therefore, we evaluated the TE of health systems and its determinants in Member States of the WHO Eastern Mediterranean Region in order to produce health outcomes.

\section{Methods}

This descriptive-analytical study was conducted using data envelopment analysis (DEA) and regression analysis to estimate the TE of health systems and its determinants in Member States of the WHO Eastern Mediterranean Region (Afghanistan, Bahrain, Djibouti, Egypt, Islamic Republic of Iran, Iraq, Jordan, Kuwait, Lebanon, Libya, Morocco, Palestinian Authority, Oman, Pakistan, Qatar, Saudi Arabia, Somalia, Sudan, Syrian Arab Republic, Tunisia, United Arab Emirates and Yemen) during 2004-2011. To measure the TE of health systems, per capita total expenditure on health, number of physicians, nurses and midwives, and number of hospital beds per 1000 people were used as input variables, and life expectancy at birth and reversed infant mortality rate were used as output variables (Table 1). The inclusion criteria included being a Member State of the WHO Eastern Mediterranean Region and completeness of the data and information about the countries.

DEA is a nonparametric linear programming model used in frontier analysis to measure the TE of decisionmaking units. Several assumptions have been made to estimate TE using the programming model according to the type of optimization. Thus, the model can be input-oriented (minimizing inputs to achieve a certain level of output) and output-oriented (maximizing output using a certain level of input). DEA assumptions in this study were considered as constant returns to scale and as maximizing outcomes with certain inputs (output-oriented). The DEA linear programming model is given as follows:

$$
\begin{aligned}
& \text { Max; } \mathrm{W}=\sum_{\mathrm{r}=1}^{\mathrm{s}} \mathrm{U}_{\mathrm{r}}^{\mathrm{k}} \cdot \mathrm{Y}_{\mathrm{rk}} \\
& \text { subject to } \sum_{\mathrm{i}=1}^{\mathrm{m}} \mathrm{V}_{\mathrm{i}}^{\mathrm{k}} \cdot \mathrm{X}_{\mathrm{ik}}=1 \\
& \sum_{\mathrm{r}=1}^{\mathrm{s}} \mathrm{U}_{\mathrm{r}}^{\mathrm{k}} \mathrm{Y}_{\mathrm{rij}}-\sum_{\mathrm{i}=1}^{\mathrm{m}} \mathrm{V}_{\mathrm{i}}^{\mathrm{k}} \cdot \mathrm{X}_{\mathrm{ij}} \leq 0 \\
& \text { for } \mathrm{j}=1, . ., n \\
& \mathrm{U}_{\mathrm{r}}^{\mathrm{k}} \geq \boldsymbol{E}>0 \mathrm{r}=1,2, \ldots, S \\
& \mathrm{~V}_{\mathrm{i}}^{\mathrm{k}} \geq \mathcal{E}>0 \mathrm{i}=1,2, \ldots, m
\end{aligned}
$$




\begin{tabular}{|c|c|c|}
\hline Variable & Definition & Role \\
\hline Health expenditure & Per capita total expenditure on health (average exchange rate; US\$) & Input in DEA model \\
\hline Physician density & $\begin{array}{l}\text { Number of physicians actively practicing medicine in public and private } \\
\text { institutions (full-time equivalents) per } 1000 \text { population }\end{array}$ & Input in DEA model \\
\hline $\begin{array}{l}\text { Nurse and midwifery } \\
\text { density }\end{array}$ & Number of nurses and midwives per 1000 population & Input in DEA model \\
\hline Bed density & Number of inpatient beds per 1000 population & Input in DEA model \\
\hline Life expectancy at birth & $\begin{array}{l}\text { Average number of years that a person at birth can be expected to live, } \\
\text { assuming that age-specific mortality levels remain constant }\end{array}$ & $\begin{array}{l}\text { Output in DEA } \\
\text { model }\end{array}$ \\
\hline Infant mortality rate & Number of deaths of infants aged $<1$ year per 1000 live births & $\begin{array}{l}\text { Output in DEA } \\
\text { model }\end{array}$ \\
\hline Education level & Literacy rate among adults aged $>15$ years $(\%)$ & $\begin{array}{l}\text { Determinant in } \\
\text { regression model }\end{array}$ \\
\hline Income per capita & Gross domestic product per capita (average exchange rate; US\$) & $\begin{array}{l}\text { Determinant in } \\
\text { regression model }\end{array}$ \\
\hline Out-of-pocket expenditure & Out-of-pocket expenditure as percentage of total health expenditure & $\begin{array}{l}\text { Determinant in } \\
\text { regression model }\end{array}$ \\
\hline Unemployment rate & $\begin{array}{l}\text { Share of the labour force that is without work but available for and seeking } \\
\text { employment }\end{array}$ & $\begin{array}{l}\text { Determinant in } \\
\text { regression model }\end{array}$ \\
\hline
\end{tabular}

$\varepsilon>0$ is a non-Archimedean infinitesimal.

Where W is the TE of the health system, Y is the output of the health system, $\mathrm{X}$ is the input or resources of the health system, $\mathrm{U}$ is the output weight, $\mathrm{V}$ is the input weight, $i-m$ is the input index, and $r-s$ is the index of output. The TE of the health systems of the 22 countries was estimated using information on per capita total expenditure, number of physicians, nurses and midwives, number of hospital beds, life expectancy at birth and reversed infant mortality rate, as a time series for 8 years (2004-2011). A decision-making unit (health system) that produced the maximum health output for a certain level of resources or input was considered as the reference unit with TE score close to 1. In contrast, a decision-making unit that used several inputs to produce the fewest health outputs was considered as inefficient with TE score close to 0 . Therefore, the TE score in DEA was a number between 1 and 0 . Information and health data were collected from the WHO Global Health Observatory database, World Bank, and statistical data of the human development indices. Win4deap 1.1.2 software was used for conducting technical efficiency of health systems.

DEA is performed using deterministic data and information (not stochastic) and the frontier function may be affected by stochastic changes, measurement error and unobservable heterogeneity of data. To overcome this, we estimated the TE of the health systems during an 8-year period rather than cross-sectionally, which also increased the power of our analysis.

In the second part of the study, the TE score obtained from the DEA model was modelled as a dependent variable and as a function of variables out of and under the control of the health systems. The regression model is given as follows:

$$
\begin{gathered}
\mathrm{LCR}_{\mathrm{it}}=\beta 0+\beta 1 \mathrm{LED}_{\mathrm{it}}+\beta 2 \mathrm{LGDP}_{\mathrm{it}}+ \\
\beta 3 \mathrm{LOOP}_{\mathrm{it}}+\beta 4 \mathrm{LU}_{\mathrm{it}}+\mathrm{u}_{\mathrm{it}}
\end{gathered}
$$

Where $\mathrm{LCR}_{\text {it }}$ is the logarithm of health system TE score of country $i$ in year $t$; $\operatorname{LED}_{\mathrm{it}}$ is the logarithm of literacy rate of those aged $>15$ years in country $i$ in year $t$; $L_{G D P}$ it s the logarithm of the GDP of country $i$ in year $t$; LOOP is the logarithm of out-of-pocket health expenditure in country $i$ in year $t ; U_{i t}$ is the logarithm of unemployment rate in country $i$ in year $t$; and $u_{i t}$ is the error term of the equation. The panel data included i observations (22 countries) during $t$ years (2004-2011). Stata version 12.0 software was used for regression analysis.

To estimate the model and avoid spurious regression, we determined the stationary and unit root of given variables. We examined panel data unit root with Levin-Lin-Chu (2002) (LLC), Augmented Dickey-Fuller (ADF)-Fisher and PP-Fisher tests. After determining the level of stationary, co-integration of variables was also examined using the Pedroni (1999) co-integration test. In addition, the Chow test was used for the detection of fixed effects and pooled models, and Hausman test was used for detection of random and fixed effects models.

\section{Results}

The descriptive statistics and the variables used in the DEA and regression model showed that during 2004-2011, the per capita total expenditure on 


\begin{tabular}{|c|c|c|c|c|c|c|c|c|c|}
\hline \multirow[t]{2}{*}{ Variable } & \multirow[t]{2}{*}{ Median } & \multirow[t]{2}{*}{ Mean } & \multirow{2}{*}{$\begin{array}{l}\text { Standard } \\
\text { Deviation }\end{array}$} & \multicolumn{3}{|c|}{ Maximum value of variables } & \multicolumn{3}{|c|}{ Minimum value of variables } \\
\hline & & & & Value & Country & Year & Value & Country & Year \\
\hline Health expenditure & 158.5 & 351.1 & 490.6 & 3416.0 & Qatar & 2008 & 1.0 & Somalia & 2011 \\
\hline Physician density & 13.4 & 13.6 & 9.2 & 35.4 & Lebanon & 2009 & 0.2 & Somalia & 2010 \\
\hline Nurse and midwifery density & 18.8 & 24.0 & 18.3 & 73.8 & Qatar & 2008 & 0.2 & Yemen & 2008 \\
\hline Bed density & 17.0 & 16.5 & 8.5 & 39.0 & Libya & 2004 & 3.9 & Afghanistan & 2004 \\
\hline Life expectancy & 72.1 & 68.6 & 9.0 & 81.5 & Lebanon & 2011 & 44.1 & Djibouti & 2007 \\
\hline Infant mortality rate & 20.8 & 38.0 & 35.3 & 147.0 & Afghanistan & 2005 & 6.8 & Qatar & 2010 \\
\hline Education level & 81.0 & 71.8 & 21.4 & 99.0 & Emirates & 2007 & 16.0 & Afghanistan & 2004 \\
\hline Income per capita & 2514.0 & 9707.3 & 16352.7 & 88990.0 & Qatar & 2009 & 158.0 & Afghanistan & 2004 \\
\hline Out-of-pocket expenditure & 40.8 & 39.9 & 20.1 & 83.1 & Iraq & 2004 & 2.4 & Saudi Arabia & 2008 \\
\hline Unemployment rate & 8.9 & 10.3 & 7.4 & 59.5 & Djibouti & 2004 & 0.3 & Qatar & 2009 \\
\hline
\end{tabular}

health was about US\$351.1 (Table 2). Thus, the maximum value of US\$3416 was found in Qatar in 2008 and the lowest value of US\$1 was found in Somalia in 2011. Somalia, Yemen and Afghanistan had the lowest number of physicians, nurses and midwives, and hospital beds. Maximum values for these variables were found in Lebanon, Qatar and Libya. The average life expectancy at birth and infant mortality in all 22 countries was 68.6 years and 38 cases per 1000 live births, respectively. The highest average life expectancy at birth and infant mortality rate were found in Lebanon and Afghanistan. Djibouti and
Qatar had the lowest average life expectancy at birth and infant mortality rate.

Based on average TE scores of the health systems during 2004-2011, the health systems of the United Arab Emirates and Somalia had full TE (score $=1$ ) and the scores systems in other countries were $<1$ (Table 3). Following

\begin{tabular}{|c|c|c|c|c|c|c|c|c|c|c|c|}
\hline Countries & 2004 & 2005 & 2006 & 2007 & 2008 & 2009 & 2010 & 2011 & $\begin{array}{c}\text { Mean } \\
(2004-11)\end{array}$ & $\begin{array}{l}\text { Change (\%) } \\
(2004-11)\end{array}$ & Rank \\
\hline Somalia & 1.00 & 1.00 & 1.00 & 1.00 & 1.00 & 1.00 & 1.00 & 1.00 & 1.00 & 0 & 1 \\
\hline United Arab Emirates & 1.00 & 1.00 & 1.00 & 1.00 & 1.00 & 1.00 & 1.00 & 1.00 & 1.00 & 0 & 1 \\
\hline Oman & 1.00 & 1.00 & 1.00 & 1.00 & 1.00 & 1.00 & 1.00 & 0.81 & 0.98 & -19 & 2 \\
\hline Syrian Arab Republic & 1.00 & 1.00 & 1.00 & 1.00 & 1.00 & 1.00 & 1.00 & 0.78 & 0.97 & -22 & 3 \\
\hline Afghanistan & 0.98 & 0.96 & 0.96 & 0.98 & 0.98 & 0.92 & 0.90 & 0.84 & 0.94 & -14 & 4 \\
\hline Bahrain & 1.00 & 0.72 & 0.87 & 0.93 & 0.98 & 1.00 & 1.00 & 0.91 & 0.93 & -9 & 5 \\
\hline Yemen & 1.00 & 0.95 & 0.82 & 0.78 & 1.00 & 1.00 & 1.00 & 0.71 & 0.91 & -29 & 6 \\
\hline Kuwait & 1.00 & 1.00 & 0.99 & 0.97 & 0.99 & 0.93 & 0.66 & 0.61 & 0.89 & -39 & 7 \\
\hline Pakistan & 0.83 & 0.96 & 0.93 & 0.58 & 0.97 & 0.92 & 0.96 & 0.90 & 0.88 & 8 & 8 \\
\hline Qatar & 0.88 & 0.78 & 0.72 & 0.77 & 0.75 & 1.00 & 1.00 & 0.87 & 0.85 & -1 & 9 \\
\hline Morocco & 1.00 & 0.98 & 0.89 & 0.82 & 0.66 & 0.70 & 0.77 & 0.74 & 0.82 & -26 & 10 \\
\hline Islamic Republic of Iran & 0.66 & 0.66 & 0.55 & 1.00 & 1.00 & 0.64 & 1.00 & 1.00 & 0.81 & 52 & 11 \\
\hline Occupied Palestine & 0.95 & 0.91 & 0.80 & 0.75 & 0.75 & 0.49 & 1.00 & 0.62 & 0.78 & -35 & 12 \\
\hline Egypt & 0.69 & 0.78 & 0.71 & 0.42 & 0.73 & 0.79 & 0.94 & 1.00 & 0.76 & 45 & 13 \\
\hline Sudan & 0.87 & 0.81 & 0.84 & 0.71 & 0.70 & 0.66 & 0.68 & 0.60 & 0.74 & -31 & 14 \\
\hline Tunisia & 0.67 & 0.77 & 0.73 & 0.76 & 0.71 & 0.61 & 0.70 & 0.60 & 0.69 & -10 & 15 \\
\hline Iraq & 0.70 & 0.39 & 0.39 & 0.65 & 0.79 & 0.84 & 0.94 & 0.72 & 0.68 & 3 & 16 \\
\hline Lebanon & 0.35 & 0.91 & 0.91 & 0.49 & 0.50 & 0.38 & 0.44 & 0.68 & 0.58 & 94 & 17 \\
\hline Jordan & 0.69 & 0.62 & 0.60 & 0.64 & 0.68 & 0.54 & 0.52 & 0.31 & 0.57 & -55 & 18 \\
\hline Saudi Arabia & 0.56 & 0.50 & 0.50 & 0.54 & 0.54 & 0.50 & 0.48 & 0.36 & 0.50 & -36 & 19 \\
\hline Libya & 0.41 & 0.40 & 0.39 & 0.35 & 0.42 & 0.45 & 0.52 & 0.53 & 0.44 & 29 & 20 \\
\hline Djibouti & 0.30 & 0.29 & 0.29 & 0.32 & 0.45 & 0.33 & 0.41 & 0.38 & 0.35 & 27 & 21 \\
\hline
\end{tabular}


the assumptions of the DEA model (assuming output-oriented and constant return to scale), it means that the health systems in the United Arab Emirates and Somalia compared well with those in other countries, using certain inputs (per capita total expenditure on health, number of physicians, nurses and midwives, and number of hospital beds), produced the maximum outputs (increased life expectancy at birth and reduced infant mortality). The health systems in Oman and the Syrian Arab Republic were ranked second and third, respectively. In contrast, this study showed the poor position of the health systems in countries such as Djibouti, Libya and Saudi Arabia, which were ranked last.

In addition, the mean TE of health systems during 2004-2011 was 0.77 . The health systems in Kuwait and Jordan had the greatest reduction in TE between 2004 and 2011. In contrast, the health systems in Lebanon and the Islamic Republic of Iran showed the greatest increase in TE. In fact, TE change provides a measure of how far each country has moved from the efficient frontier (the set of health systems that offer the highest outputs for a defined level of inputs) over the time period.

According to LLC and ADF-Fisher tests, all the studied variables were first-order stationary (Table 4). However, the PP-Fisher test showed that all variables except unemployment rate were first-order stationary. According to both statistics of the Pedroni test, the null hypothesis could not be confirmed due to lack of co-integration of the model. Therefore, the variables studied were co-integrated and the problem of spurious regression in estimating the model was not encountered. The results of the $F$ and $\chi^{2}$ statistics of the Chow test showed that the dominant and appropriate model was a random and fixed effects model, respectively. In order to test the random or fixed effects model we conducted the Hausman test. The dominant model according to Hausman's test was a fixed effects model.

In the regression model, in order to investigate the determinants of health system TE, several variables (out of and under the control of the health systems) were considered as factors affecting health production function (Table 5). Level of education, per capita GDP and unemployment rate as factors out of the control of the health systems, and out-of-pocket expenditure as a factor under the control of health systems or as an input indicator were entered into the model. The effect of each of these variables on the TE score was examined. The regression model showed that literacy rate of those aged $>15$ years (indicative of education) and per capita GDP had a significant effect on the TE of health systems. Unemployment rate and payment by people for health care had no significant relationship with TE.

\section{Discussion}

This study was conducted to evaluate the TE of health systems and its determinants in the Member States of the WHO Eastern Mediterranean Region during 2004-2011. Somalia and the United Arab Emirates with an average TE score of 1 had the most efficient health systems. However, in a study by Evans et al. (2), the TE of the health systems of 191 countries was evaluated in terms of health production, in which Somalia and the United Arab Emirates were ranked 154 (score of 0.506) and 16 (score of 0.907), respectively. In the present study, the health system of Oman was ranked second, while in other studies (15), the TE score for Oman's health system in achieving the desired outputs (life expectancy, reduction in infant and age $<5$ years mortality rates, and fertility rate) in 2008 was 0.988 (6th out of 22 countries). The differences can be attributed to the different countries studied, inputs and outputs, DEA model and assumptions

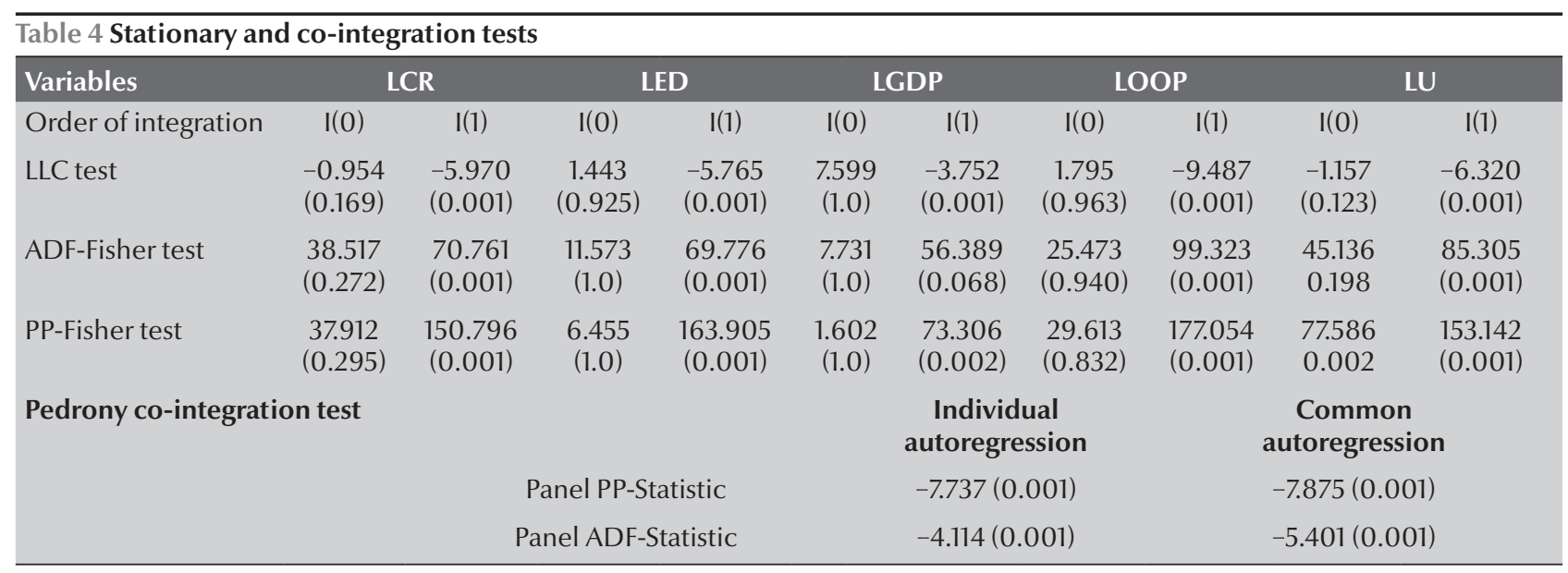

$L L C=$ Levin-Lin-Chu (2002); $A D F=$ Augmented Dickey-Fuller; $L E D=$ logarithm of education; $L G D P=$ logarithm of gross domestic product; $L O O P=$ logarithm of out-ofpocket payment; $L U=$ logarithm of unemployment rate. 


\begin{tabular}{|c|c|c|}
\hline Variables & Coefficient & $P$ \\
\hline C & -3.699 & 0.001 \\
\hline LED & 0.527 & 0.02 \\
\hline LGDP & 0.154 & 0.04 \\
\hline LOOP & -0.030 & 0.61 \\
\hline LU & 0.003 & 0.95 \\
\hline & & $\begin{array}{l}\text { Adjusted } R 2=0.7 \\
\text { DW statistic }=1.6\end{array}$ \\
\hline
\end{tabular}

$C=$ constant coefficient $; D W=$ Durbin - Watson; $L E D=$ logarithm of education; $L G D P=$ logarithm of gross domestic product; $L O O P=$ logarithm of out-of-pocket payment; $L U=$ logarithm of unemployment rate.

considered (returns to scale and inputor output-oriented).

The presentstudy showed that some countries per certain unit of resources produced more health outcomes. For example, Somalia with the lowest per capita total health expenditure (average US\$1) and number of physicians per 1000 persons (0.2) had the maximum TE. It is expected that further investment in health systems (including Somalia) will yield better health outcomes. In terms of TE changes during 2004-2011, we showed that the TE of the health systems of Lebanon and the Islamic Republic of Iran had the highest increase. The increase can be attributed to the appropriate use of health system resources, increased life expectancy and reduced infant mortality. In contrast, Kuwait and Jordan had the greatest reduction in TE.

We draw attention to 2 important issues. First, for health systems with 0 input, the output level will not also be 0 (16). In other words, even in the absence of the health system, a level of output will be achieved because a large part of the individual's health is determined outside the health system. Second, concern about the rate of diminishing marginal returns is of importance in achieving health gains. The rate of diminishing marginal returns can begin from a certain level of health outcomes, and from this point, countries should spend more for each unit of health outcomes.

Several studies have shown that factors out of the control of the health systems play an important role in the health status of the community $(3,17-$ 19). Therefore, in our regression model, the literacy rate of those aged $>15$ years, per capita GDP and unemployment rate were used as components out of the control of the health system, and outof-pocket expenditure was used as the only component under the control of the health system. The regression model showed that in the long term, out-ofpocket expenditure had no significant effect on the TE of the health systems. In contrast, the level of education and GDP per capita had the greatest effect on TE. Therefore, public health status is affected by education and income as well as health systems. Educated and high-income people are capable of effective use of health information and services to improve their health status. Unhealthy behaviour is associated with low levels of education and income, and plays an important role in increasing mortality risk (20-22). For this reason, it has been stated that encouragement of healthy behaviour and policies to improve socioeconomic status are of importance to improve individual health status (23).

In conclusion, our study showed that the health systems of Somalia, United Arab Emirates and Oman had the highest TE score during 2004-2011. Lebanon and the Islamic Republic of Iran had the greatest change in TE and Kuwait and Jordan had the greatest decline. The results also showed that the TE of health systems was affected by factors not under the control of the health systems (e.g., level of education and GDP per capita). Therefore, to improve the TE of health systems and improve health outcomes, countries should focus on individual empowerment in the field of education and income level rather than focusing solely on providing health services.

\section{Acknowledgements}

We would like to express our gratitude to Tehran University of Medical Sciences for funding this study.

Funding: This study was funded and supported by Tehran University of Medical Sciences (TUMS) (Grant No. 92-01-27-21693).

Competing interests: None declared.

\section{References}

1. The World health report: 2000: health systems: improving performance. Geneva: World Health Organization; 2000 (http://www.who.int/whr/2000/en/, accessed 6 April 2017).

2. Evans DB, Tandon A, Murray CJ, Lauer JA. The comparative efficiency of national health systems in producing health: an analysis of 191 countries. World Health Organization (GPE Discussion Paper Series: No. 29; http://www.who.int/healthinfo/paper29.pdf, accessed 6 April 2017).
3. Hadad S, Hadad Y, Simon-Tuval T. Determinants of healthcare system's efficiency in OECD countries. Eur J Health Econ. 2013 Apr;14(2):253-65. PMID:22146798

4. Hollingsworth B. Non-parametric and parametric applications measuring efficiency in health care. Health Care Manage Sci. 2003 Nov;6(4):203-18. PMID:14686627

5. Barros CP, de Menezes AG, Peypoch N, Solonandrasana B, Vieira JC. An analysis of hospital efficiency and productivity 
1. growth using the Luenberger indicator. Health Care Manage Sci. 2008 Dec;11(4):373-81. PMID:18998596

2. Dimas G, Goula A, Soulis S. Productive performance and its components in Greek public hospitals. Oper Res. 2012 May;12(1):15-27.

3. Jehu-Appiah C, Sekidde S, Adjuik M, Akazili J, Almeida SD, Nyonator F, et al. Ownership and technical efficiency of hospitals: evidence from Ghana using data envelopment analysis. Cost Eff Resour Alloc. 2014 Apr 8;12(1):9. PMID:24708886

4. Santelices CE, Ormeno $\mathrm{CH}$, Delgado SM, Lui MC, Valdes VR, Duran CL. [Analysis of hospital technical efficiency during 2011]. Rev Med Chil. 2013 Mar;141(3):332-7 (in Spanish). PMID:23900324

5. Kirigia JM, Asbu EZ. Technical and scale efficiency of public community hospitals in Eritrea: an exploratory study. Health Econ Rev. 2013 Mar 16;3(1):6. PMID:23497525

6. Spinks J, Hollingsworth B. Cross-country comparisons of technical efficiency of health production: a demonstration of pitfalls. Appl Econ. 2009;41(4):417-27.

7. Schwellnus C. Achieving higher performance: enhancing spending efficiency in health and education in Mexico. Paris: Organisation for Economic Co-operation and Development; 2009 (OECD Economics Department Working Papers, No. 732; http://www.oecd-ilibrary.org/docserver/download/220731242856.pdf?expires=1491467907\&id=id\&accnam $\mathrm{e}=$ guest\&checksum=1A41DD2BA8574D00E3E66CE74E4EA8 7F, accessed 6 April 2017)

8. Economou C, Giorno C. Improving the performance of the public health care system in Greece. Paris: Organisation for Economic Co-operation and Development; 2009 (OECD Economics Department Working Papers, No. 722; http://www. oecd-ilibrary.org/docserver/download/221250170007.pdf?e xpires $=1491467969 \&$ id=id \&accname $=$ guest $\&$ checksum $=50 \mathrm{C}$ E23E70CFFEE4B8D1F6DD98C272482, accessed 6 April 2017)

9. Retzlaff-Roberts D, Chang CF, Rubin RM. Technical efficiency in the use of health care resources: a comparison of OECD countries. Health Policy. 2004 Jul;69(1):55-72.
10. Bhat VN. Institutional arrangements and efficiency of health care delivery systems. Eur J Health Econ. 2005 Sep;6(3):215-22. PMID:15864675

11. Rezapoor A, Ebadifard Azar F. Abbasi broujeni P. Situation of resource allocation in Iranian,s health system. Hospital J. 2013;11(4):53-64.

12. Cordero-Ferrera JM, Crespo-Cebada E, Murillo-Zamorano LR. Measuring technical efficiency in primary health care: the effect of exogenous variables on results. J Med Syst. 2011 Aug;35(4):545-54. PMID:20703536

13. López-Casasnovas G, Soley-Bori M. The socioeconomic determinants of health: economic growth and health in the OECD countries during the last three decades. Int J Environ Res Public Health. 2014 Jan 8;11(1):815-29. PMID:24406664

14. Präg P, Mills M, Wittek R. Income and income inequality as social determinants of health: do social comparisons play a role? Eur Sociol Rev. 2014;30(2):218-29.

15. Braveman P, Gottlieb L. The social determinants of health: it's time to consider the causes of the causes. Public Health Rep. 2014 Jan-Feb;129 Suppl 2:19-31. PMID:24385661

16. Lim SS, Vos T, Flaxman AD, Danaei G, Shibuya K, AdairRohani $\mathrm{H}$, et al. A comparative risk assessment of burden of disease and injury attributable to 67 risk factors and risk factor clusters in 21 regions, 1990-2010: a systematic analysis for the Global Burden of Disease Study 2010. Lancet. 2013 Dec 15;380(9859):2224-60. PMID:23245609

17. Kujala UM, Kaprio J, Koskenvuo M. Modifiable risk factors as predictors of all-cause mortality: the roles of genetics and childhood environment. Am J Epidemiol. 2002 Dec 1;156(11):985-93. PMID:12446254

18. Laaksonen M, McAlister AL, Laatikainen T, Drygas W, Morava E, Nüssel E, et al. Do health behavior and psychosocial risk factors explain the European East-West gap in health status? Eur J Public Health. 2001 Mar;11(1):65-73. PMID:11276574

19. Isaacs SL, Schroeder SA. Class-the ignored determinant of the nation's health. N Engl J Med. 2004 Sep 9;351:1137-42. PMID:15356313 